\title{
Antimicrobial compounds produced by Lactobacillus sakei subsp. sakei 2a, a bacteriocinogenic strain isolated from a Brazilian meat product
}

\author{
Kátia G. de Carvalho $\cdot$ Felipe H. S. Bambirra $\cdot$ Monika F. Kruger $\cdot$ Matheus S. Barbosa • \\ Jamil S. Oliveira · Alexandre M. C. Santos · Jacques R. Nicoli • Marcelo P. Bemquerer • \\ Antonio de Miranda $\cdot$ Emiliano J. Salvucci $\cdot$ Fernando J. M. Sesma $\cdot$ Bernadette D. G. M. Franco
}

Received: 21 October 2009/Accepted: 10 December 2009/Published online: 27 December 2009

(C) Society for Industrial Microbiology 2009

\begin{abstract}
Bacteriocins produced by lactic acid bacteria are gaining increased importance due to their activity against undesirable microorganisms in foods. In this study, a concentrated acid extract of a culture of Lactobacillus sakei subsp. sakei 2a, a bacteriocinogenic strain isolated from a Brazilian pork product, was purified by cation exchange and reversed-phase chromatographic methods. The amino acid sequences of the active antimicrobial compounds determined by Edman degradation were compared to known protein sequences using the BLAST-P software. Three different antimicrobial compounds were obtained, P1, P2 and P3, and mass spectrometry indicated molecular masses of 4.4, 6.8 and $9.5 \mathrm{kDa}$, respectively. P1
\end{abstract}

K. G. de Carvalho - M. F. Kruger - M. S. Barbosa

B. D. G. M. Franco ( $\square)$

Departamento de Alimentos e Nutrição Experimental,

Faculdade de Ciências Farmacêuticas,

Universidade de São Paulo, Avenida Professor Lineu Prestes,

580, Cidade Universitária, P. O. Box 05508-900,

São Paulo, SP, Brazil

e-mail: bfranco@usp.br

K. G. de Carvalho

e-mail: ka20_04@hotmail.com

J. S. Oliveira - A. M. C. Santos · M. P. Bemquerer

Departamento de Bioquímica e Imunologia, Instituto de Ciências

Biológicas, Universidade Federal de Minas Gerais,

Belo Horizonte, MG, Brazil

F. H. S. Bambirra · J. R. Nicoli

Departamento de Microbiologia, Instituto de Ciências

Biológicas, Universidade Federal de Minas Gerais,

Belo Horizonte, MG, Brazil

M. P. Bemquerer

Embrapa Recursos Genéticos e Biotecnologia Parque Estação

Biológica, Brasília, DF, Brazil corresponds to classical sakacin P, P2 is identical to the $30 \mathrm{~S}$ ribosomal protein $\mathrm{S} 21$ of $L$. sakei subsp. sakei $23 \mathrm{~K}$, and P3 is identical to a histone-like DNA-binding protein HV produced by L. sakei subsp. sakei $23 \mathrm{~K}$. Total genomic DNA was extracted and used as target DNA for PCR amplification of the genes sak, lis and his involved in the synthesis of P1, P2 and P3. The fragments were cloned in pET28b expression vector and the resulting plasmids transformed in E. coli KRX competent cells. The transformants were active against Listeria monocytogenes, indicating that the activity of the classical sakacin P produced by $L$. sakei 2 a can be complemented by other antimicrobial proteins.
A. de Miranda

Departamento de Biofisica, Universidade Federal de São Paulo, São Paulo, SP, Brazil

K. G. de Carvalho - E. J. Salvucci - F. J. M. Sesma Centro de Referencia para Lactobacilos (CERELA), Tucumán, Argentina

A. M. C. Santos

Departamento de Ciências Fisiológicas, Universidade Federal do Espírito Santo, Vitória, ES, Brazil 
Keywords Lactobacillus sakei $2 \mathrm{a} \cdot$ Bacteriocins . Antimicrobial proteins $\cdot$ Lactic acid bacteria

\section{Introduction}

Lactic acid bacteria produce a variety of substances with antimicrobial activity, including antimicrobial peptides collectively known as bacteriocins [23], which are able to inhibit foodborne pathogens and spoilage bacteria [12, 14, $15,20,32]$. Several classifications have already been proposed [12, 30, 31], but according to the most recent one [2, $23,36]$, bacteriocins are grouped into four classes, based on their structure and function: class I: lantibiotic peptides, class II: small non-modified peptides with molecular mass $<10 \mathrm{kDa}$, class III, large proteins with molecular mass $>10 \mathrm{kDa}$. Bacteriocins of class II are subdivided into three subgroups: type IIa corresponds to pediocin-like bacteriocins, type IIb are multicomponent bacteriocins and type IIc are miscellaneous bacteriocins, a diverse group that includes sakacins $\mathrm{Q}, \mathrm{T}$ and $\mathrm{X}$.

Lactobacillus sakei subsp. sakei $2 \mathrm{a}$ is a bacteriocinogenic lactic acid bacterium isolated from a Brazilian pork sausage that is capable of inhibiting the growth and the pathology of Listeria monocytogenes in culture media, in food systems and in the murine gastrointestinal tract $[4,13$, 33]. The bacteriocin produced by this strain forms pores in the membrane of target cells, dissipates the proton motive force in sensitive L. monocytogenes Scott A, reduces the intracellular ATP concentration with no detectable increase in extracellular ATP and mediates a concentration-dependent efflux of 5(6)-carboxyfluorescein from liposomes prepared from L. monocytogenes lipids [8, 35, 39, 42].

The purification protocol used by Rosa et al. [39] was based on salt extraction, cation exchange and reversedphase chromatography. Many other strategies have been reported in the literature for the purification of antimicrobial peptides and proteins produced and secreted by bacteria $[1,3,9,21,34,40,41,44,47]$. Generally, the first step is a precipitation with ammonium sulphate [29] or an aqueous extraction of secreted compounds by medium acidification to release cationic compounds bound to the bacteria cell wall [27]. An obvious strategy for the enrichment of those cationic antimicrobial peptides and proteins is a fractionation by ion-exchange chromatography $[5,6,11]$.

The fractionation of antimicrobial compounds by cation exchange and reversed-phase chromatography suggests that the Lactobacillus sakei subsp. sakei 2 a strain is capable of producing more than one antimicrobial peptide. The purpose of this study was to purify and characterize these molecules, using Edman degradation and comparison to protein sequences deposited on the Basic Local Alignment Search Tool (BLAST-P) program.

\section{Materials and methods}

Bacterial cultures and media

The following strains were used (Table 1): For use, L. sakei 2a was grown at $25^{\circ} \mathrm{C}$ for $18 \mathrm{~h}$ in MRS broth (Difco, Detroit, MI), whereas L. monocytogenes and the other cultures were grown at $37^{\circ} \mathrm{C}$ for $24 \mathrm{~h}$ in BHI broth (Difco, Detroit, MI).

Assay for antibacterial activity

Antibacterial activity was assayed by the double layer diffusion test, according to Farias et al. [16]. Ten microliters of the testing material was spotted onto the surface of plates containing BHI agar (Difco). The plates were allowed to dry, over-layed with $5 \mathrm{ml}$ semi-solid BHI agar containing $40 \mu \mathrm{l}$ of a culture of the indicator

Table 1 Bacteriogenic and target strains used

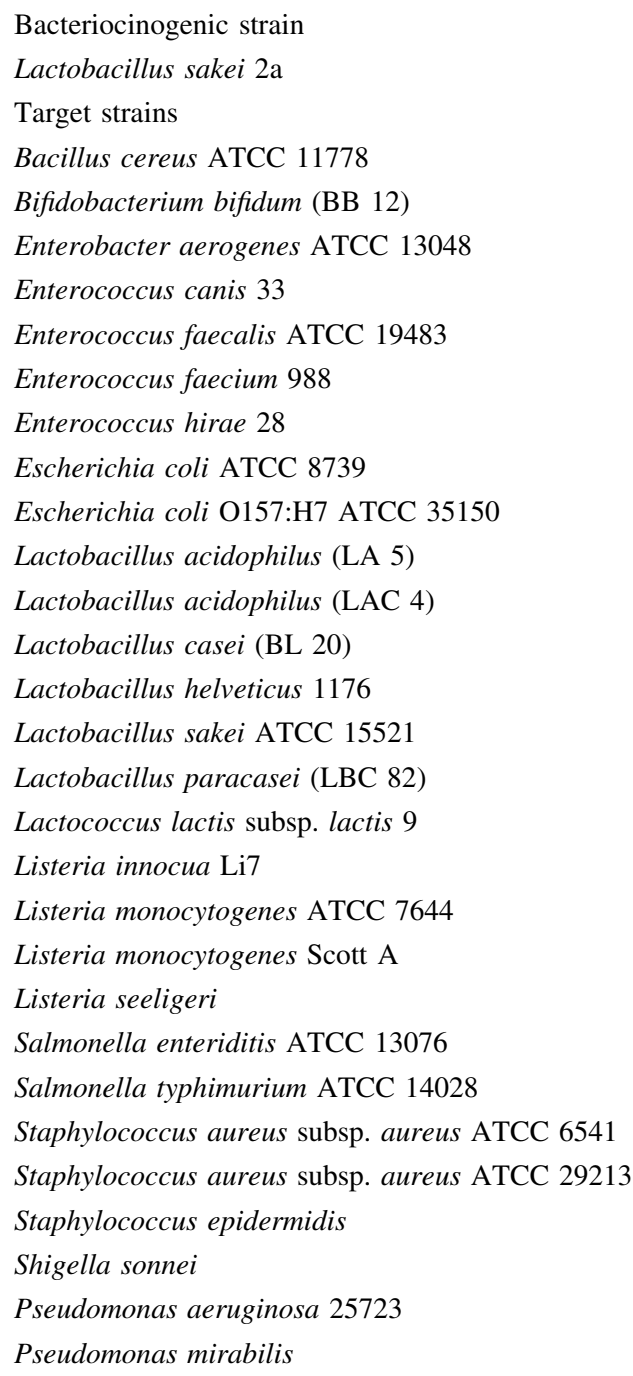

Bacteriocinogenic strain

Lactobacillus sakei 2 a

Target strains

Bacillus cereus ATCC 11778

Bifidobacterium bifidum (BB 12)

Enterobacter aerogenes ATCC 13048

Enterococcus canis 33

Enterococcus faecalis ATCC 19483

terococcus faecium 988

Escherichia coli O157:H7 ATCC 35150

Cidophilus (LA 5)

Letobacillus acidophilus (LAC 4)

Lactobacillus casei (BL 20)

Lactobacillus helveticus 1176

Lactobacillus sakei ATCC 1552

Lactobacillus paracasei (LBC 82)

Lactococcus lactis subsp. lactis 9

Listeria innocua $\mathrm{Li} 7$

Listeria monocytogenes ATCC 7644

Listeria monocytogenes Scott A

Listeria seeligeri

Salmonella enteriditis ATCC 13076

. aureus ATCC 29213

Staphylococcus epidermidis

ella sonne

Pseudomonas mirabilis 
microorganism $\left(10^{8} \mathrm{CFU} \mathrm{ml}{ }^{-1}\right)$ and incubated at $37^{\circ} \mathrm{C}$ for $24 \mathrm{~h}$. The formation of an inhibition halo around the spotted material indicated a positive antagonistic result. The double layer diffusion test was used to determine bacteriocin activity at each step of the purification. Bacteriocin activity was determined using titers of a twofold dilution. A unit of bacteriocin activity was defined as the reciprocal of the highest dilution having a detectable zone of inhibition and expressed as $\mathrm{AU} \mathrm{ml}{ }^{-1}$.

Extraction of the antimicrobial compounds adsorbed to the $L$. sakei 2 a cells

Eight liters of MRS broth was inoculated with $1 \%(\mathrm{v} / \mathrm{v})$ of an overnight $L$. sakei 2 a culture in MRS broth at $25^{\circ} \mathrm{C}$, and L. sakei $2 \mathrm{a}$ was grown to early stationary phase (about $5 \times 10^{8} \mathrm{CFU} \mathrm{ml}{ }^{-1}$ ). Then, $\mathrm{pH}$ was adjusted to 6.0 and the medium heated to $70^{\circ} \mathrm{C}$ for $30 \mathrm{~min}$ before cell harvesting by centrifugation at $10,000 \mathrm{~g}$ for $15 \mathrm{~min}$. Supernatant activity was assayed for bacteriocin not adsorbed onto the cells. After washing with $5 \mathrm{mmol}^{-1} 2$-( $N$-morpholin)ethanesulphonate (MES) buffer, $\mathrm{pH}$ 6.5, the cells were suspended in $400 \mathrm{ml}$ of $100 \mathrm{mmol}^{-1} \mathrm{NaCl}, \mathrm{pH} 1.5$ (adjusted with 5\% phosphoric acid), and mixed with a magnetic stirrer for $1 \mathrm{~h}$ at $4^{\circ} \mathrm{C}$ [49]. Cell suspensions were centrifuged at 10,000 $\mathrm{g}$ for $20 \mathrm{~min}$, and the supernatant was concentrated ten times by ultra-filtration in an Amicon System (Millipore Ind. Com. Ltda, SP, Brazil) with a 1.000-molecular-weight-cutoff membrane and then freezedried. The protein concentration in the product was determined by the Bradford method [7].

Purification of the antimicrobial compounds

The acid extract from $L$. sakei $2 \mathrm{a}$ was fractionated by cation exchange chromatography using a MONO-S (HR5/ 5-Amersham) column coupled to a FPLC system (Pharmacia, GMI, Ramsey, MN). The mobile phases were the

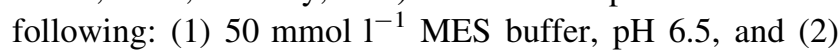
$50 \mathrm{mmol}^{-1}$ MES buffer, pH 6.5, plus $1.0 \mathrm{mmol} \mathrm{l}^{-1}$ of

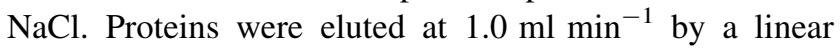
$\mathrm{NaCl}$ gradient, from 0 to $1 \mathrm{~mol}^{-1}$ in $75 \mathrm{~min}$ with detection at $280 \mathrm{~nm}$. Fractions presenting antimicrobial activity against L. monocytogenes Scott A and Enterococcus faecalis ATCC 19483 were separately injected in a $\mathrm{C}_{18}$-reversed-phase column (Shim-Pack ODS, $250 \times 4.6$ $\mathrm{mm}, 5 \mu \mathrm{m}$ ) coupled to a HPLC system (Shimadzu, Kyoto, Japan). Mobile phases used were as follows: (1) aqueous solution of trifluoroacetic acid (TFA) at $0.1 \%$ (by volume) and (2) aqueous solution of acetonitrile at $80 \%$ (by volume) containing $0.1 \%$ TFA (by volume). The compounds were eluted by a linear gradient at $1.0 \mathrm{ml} \mathrm{min}^{-1}$, increasing phase B from 0 to $100 \%$ during $30 \mathrm{~min}$. The eluted compounds presenting absorbance at $280 \mathrm{~nm}$ were assayed against $L$. monocytogenes Scott A and E. faecalis ATCC 19483 , and those presenting activity were submitted to characterization by $\mathrm{N}$-terminal protein sequencing and mass spectrometry.

\section{Protein sequencing}

The amino acid sequences of the active antimicrobial compounds were determined by Edman degradation in a automated protein sequencer (Shimadzu PPSQ-21A, Shimadzu, Kyoto, Japan) coupled to a reversed-phase separation of PTH-amino acids in a WAKOSIL-PTH $(4.6 \times 250 \mathrm{~mm})$ column (Wako, Osaka, Japan) at $1.0 \mathrm{ml} \mathrm{min}{ }^{-1}$, with detection at $235 \mathrm{~nm}$. The obtained sequences were compared to known protein sequences using the BLAST-P software.

\section{Mass spectrometry}

The average molecular mass of the antimicrobial compounds was determined by electrospray ionization mass spectrometry (ESI-Q-TOF Micro ${ }^{\circledR}$, Micromass, UK) in the positive ion mode. Mass spectrometer calibrations were made using sodium iodide in the $100-2,500 \mathrm{~m} / \mathrm{z}$ range. The analytes were solubilized in $100 \mu \mathrm{l}$ of $50 \%$ (v/v) acetonitrile in aqueous $0.2 \%(\mathrm{v} / \mathrm{v})$ formic acid at a final concentration ranging from 10 to $30 \mu \mathrm{mol} 1^{-1}$, and applied to the mass spectrometer by a syringe pump system at a flow rate of $10 \mu 1 \mathrm{~min}^{-1}$. The capillary and the cone voltages were $2.5 \mathrm{kV}$ and $40 \mathrm{~V}$, respectively. The final spectrum was the result of 20 combined scans. Original data $(\mathrm{m} / \mathrm{z})$ were treated (base line subtraction, smoothing and centring), and mass spectrum data were analyzed by the Masslynx ${ }^{\circledR} 4.0$ software. The multiply-charge distribution spectra were converted to singly charged spectra by using the computer algorithm "Transform included in pack of analysis of Q-tof Micromass."

Cloning of genes involved in the synthesis of $\mathrm{P} 1, \mathrm{P} 2$ and $\mathrm{P} 3$ in $E$. coli

Total genomic DNA was extracted from L. sakei 2a using a Wizard $^{\circledR}$ Genomic DNA Purification System (Promega, Madison, WI) and used as target DNA for PCR amplification of the genes (sak, lis and his) involved in the synthesis of three antimicrobial compounds (P1, P2 and P3) selected among those produced by the $L$. sakei $2 \mathrm{a}$ strain, after their purification and sequencing. For PCR amplification of sak (P1), lis (P2) and his (P3) genes, the following primers were used: (5'-CCATGGATGAAATATTATGGTA ACGGTGAG- $3^{\prime}$ and $5^{\prime}$-GGATCCTTATTTATTCCAGCC AGCGTTTC- $\left.{ }^{\prime}\right),\left(5^{\prime}\right.$-CCATGGGCAAGACAGTCGTTCG- $3^{\prime}$ 
and $5^{\prime}$-GGATCCTTAGAATTTCTTACGTTTTCTTGC-3') and $\left(5^{\prime}\right.$-CCATGGCAAACAAAGCACAATTG- $3^{\prime}$ and $5^{\prime}-\mathrm{GG}$ ATCCTTATTAACAGAATCCTTTAAAG- $3^{\prime}$ ), respectively. The fragments of $s a k$, lis and his genes were cloned in pET28b expression vector (Novagen/EMD/Merck, USA) according to the procedure recommended by the manufacturer, and the resulting plasmids (pET:sak, pET:lis and pET:his), using NcoI and BamHI sites, transformed in E. coli KRX competent cells (Promega, USA) [22]. Transformants were selected on Luria-Bertani (LB) plates with neomycin $50 \mu \mathrm{g} \mathrm{ml}^{-1}$ at $37^{\circ} \mathrm{C}$ for $24 \mathrm{~h}$. The selection and identification of colonies containing plasmids sak, lis and his with inserts in the correct orientation were performed by PCR amplification of DNA from single E. coli colonies using primers sak, lis and his and $\mathrm{T} 7$ Terminator (5'-GCTAGTTATTGCTCAGCGG-3'). Transformed $E$. coli $\mathrm{KRX}$ was grown on LB medium, supplemented with neomycin $50 \mu \mathrm{g} \mathrm{ml}^{-1}$, and incubated at $37^{\circ} \mathrm{C}$. Induction of the $\mathrm{T} 7$ promoter of pET28b (Novagen) was carried out as follows: an overnight culture was diluted 1:200 into fresh medium and incubated at $37^{\circ} \mathrm{C}$ until the optical density at $600 \mathrm{~nm}$ reached 0.6 . The culture was then induced by adding $0.1 \%$ of rhamnose. A non-induced culture was used as control. Cultures were incubated at $25^{\circ} \mathrm{C}$ overnight and the cells harvested by centrifugation at $6,000 \mathrm{~g}$ for $10 \mathrm{~min}$. Cells were broken by the Mini BeadBeater-8 (BioSpec Products, Inc., Bartlesville, OK) in PBS buffer, and broken cells were centrifuged at $6,000 \mathrm{~g}$ for $10 \mathrm{~min}$. Supernatants were evaluated for antimicrobial activity using L. monocytogenes Scott A as indicator strain, using the double-layer diffusion assay [16]. The molecular mass of the cloned peptides was confirmed by mass spectrometry, as described previously.

\section{Heat treatment and effect of enzymes}

To characterize the antimicrobial compounds, the producer strain was cultivated in MRS broth for $18 \mathrm{~h}$ at $37^{\circ} \mathrm{C}$. Cells were removed by centrifugation $\left(13,000 \mathrm{~g}, 10 \mathrm{~min}, 4^{\circ} \mathrm{C}\right)$, and the cell-free culture supernatant fluid was considered to be crude antimicrobial compounds. First, the influence of the proteases trypsin, proteinase $\mathrm{K}$ and pronase on antilisterial activity was tested. All enzymes were dissolved in $3 \mathrm{mmol} \mathrm{l}^{-1}$ potassium phosphate buffer ( $\mathrm{pH}$ 7.5) and added to the cell-free culture supernatant fluid sample. After incubation for $24 \mathrm{~h}$ at $37^{\circ} \mathrm{C}$, the inhibitory activity was evaluated. The heat sensitivity was tested. The cellfree culture supernatant fluid was heated at $60^{\circ} \mathrm{C}$ for 15,30 , 45 and $60 \mathrm{~min}$, at $98^{\circ} \mathrm{C}$ for 15,30 and $45 \mathrm{~min}$, and at $121^{\circ} \mathrm{C}$ for $15 \mathrm{~min}$, before testing the activity. To test the influence of $\mathrm{pH}$, the solution of the antimicrobial compounds was adjusted to a $\mathrm{pH}$ of 3.0, 4.0, 5.0, 6.0, 7.0, 8.0, 9.0 or 10.0 with $\mathrm{HCl}$ or $\mathrm{NaOH}$, mixed and allowed to stand for a few minutes before testing the inhibitory activity. The activity was checked as described above.

Measurements of proton motive force and $\mathrm{pH}$ gradient

The membrane potential $(\Delta \Psi)$ of $L$. monocytogenes Scott A cells was qualitatively measured with the fluorescent probe 3,39-dipropylthiadicarbocyanine iodide [(DiSC3(5)] (Molecular Probes Inc, Eugene, OR). Cells were harvested in the log phase (optical density at $660 \mathrm{~nm}$ ), washed twice with ice-cold $50 \mathrm{mmol}^{-1}$ potassium HEPES (K-HEPES) buffer, $\mathrm{pH} 7.0$, resuspended in the same buffer to $1 / 100$ of their initial volume and stored on ice. Glucose-energized L. monocytogenes Scott A cells (final OD660, 0.6) were added to a stirred cuvette containing $2 \mathrm{ml}$ of the K-HEPES buffer and $10 \mu \mathrm{l} \operatorname{DiSC} 3(5)\left(5 \mathrm{mmol} \mathrm{l}^{-1}\right)$. Next, $2 \mu \mathrm{l}$ nigericin $\left(1.5 \mathrm{nmol} \mathrm{l}^{-1}\right)$, which dissipates the $\mathrm{pH}$ gradient $(\Delta \mathrm{pH})$, and purified antimicrobial compound $\left(10 \mathrm{nmol} 1^{-1}\right.$, $100 \mathrm{nmol} \mathrm{l}^{-1}$ e $1 \mu \mathrm{mol} \mathrm{l}^{-1}$ ) were added.

Fluorescence measurements were performed with a Cary Eclipse spectrofluorometer (Varian, CA) with a band-pass width of $5 \mathrm{~nm}$ and wavelengths of 643 and $666 \mathrm{~nm}$ for excitation and emission, respectively. The transmembrane $\Delta \mathrm{pH}$ was measured by loading L. monocytogenes Scott A cells (OD660, 0.6) with the fluorescent probe $2^{\prime}-7^{\prime}$ bis(carboxyethyl)-5(6)-carboxyfluorescein acetoxymethyl ester (BCECF AM) (Molecular Probes Inc.) by using an acid shock. Glucose-energized, BCECF-loaded cells (final OD660, 0.6) were added to a stirred cuvette containing $2 \mathrm{ml}$ of $50 \mathrm{mmol} \mathrm{1}^{-1} \mathrm{KPi}$ buffer, $\mathrm{pH}$ 6.0. Next, $2 \mu \mathrm{l}$ valinomycin (1.5 nmol $\left.1^{-1}\right)$, which dissipates the $\Delta \Psi$, and purified antimicrobial compound $\left(10 \mathrm{nmol} 1^{-1}, 100 \mathrm{nmol}^{-1} \mathrm{e}\right.$ $\left.1 \mu \mathrm{mol} \mathrm{l}^{-1}\right)$ or $2 \mu \mathrm{l}$ nigericin $\left(1.5 \mathrm{nmol}^{-1}\right)$ were added. Fluorescence was measured with band-pass widths of 5.0 and $15.0 \mathrm{~nm}$ and wavelengths of 500 and $525 \mathrm{~nm}$ for excitation and emission, respectively.

\section{Results and discussion}

Bacteriocins are secreted in the culture medium, but due the cationic characteristics and high isoelectric points, large amounts remain bound to the producing bacteria cell wall. Harsh treatment of the cells, such as heating for $30 \mathrm{~min}$ at $70^{\circ} \mathrm{C}$ and then exposure to $\mathrm{pH} 1.5$ for $60 \mathrm{~min}$, are strategies to release the proteins bound to the cell wall without causing extensive leakage from the cells [17, 39]. In the present study, the same active compounds were detected in the supernatant and in the acid-treated material. In addition, the crude acid extract did not contain typical intracellular proteins, confirming that the cell leakage was minimal or even absent. 


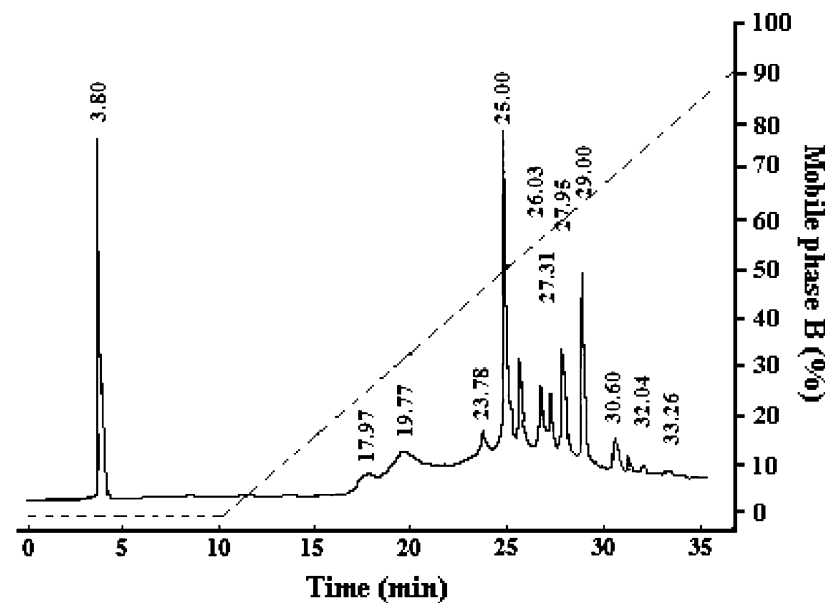

Fig. 1 Reversed-phase HPLC profile of active fractions obtained by cation-exchange fractionation of the acid extract of $L$. sakei $2 \mathrm{a}$. Separation was conducted in a Shim-Pack ODS column $(250 \times 4.6 \mathrm{~mm}, 5 \mu \mathrm{m})$ at room temperature. Mobile phases A and $\mathrm{B}$ were $0.1 \%$ aqueous trifluoroacetic acid (TFA) and $80 \%$ aqueous acetonitrile containing $0.1 \%$ TFA, respectively; flow rate was $1.0 \mathrm{ml} \mathrm{min}{ }^{-1}$, and detection was conducted at $280 \mathrm{~nm}$. The dashed line indicates the variation of percentage of mobile phase $\mathrm{B}$

Application of the acid extract of L. sakei 2a culture onto a cation-exchange Mono-S column resulted in an active fraction in the range from 0.35 to $0.55 \mathrm{~mol}^{-1} \mathrm{NaCl}$ (Fig. 1). As shown in Table 2, the procedure resulted in a satisfactory purification factor (55.2). It is important to point out that this active fraction is still a mixture of different cationic antimicrobial peptides and proteins. The application of the pooled fractions onto a $\mathrm{C}_{18}$-reversedphase $\mathrm{C} 18$ column separated several substances active against L. monocytogenes Scott A and E. faecalis ATCC 19483, as well as against some other target strains (Table 3). Protein fractions exhibiting antibacterial activity were pooled and re-fractionated using $\mathrm{C}_{18}$-reversed-phase chromatography, until purity levels higher than $95 \%$ were achieved. The protein identities were confirmed by mass spectrometry and Edman degradation. Three proteins (P1, $\mathrm{P} 2$ and $\mathrm{P} 3$ ) were consistently present in all repetitions of the purification experiments. It was not possible to calculate the purification factor for these isolated proteins and peptide due to the reduced amount of material obtained, which was employed for antimicrobial assays and protein identification. The ESI Q-TOF mass spectra and the profiles of re-fractioned proteins in $\mathrm{C}_{18} \mathrm{RPC}$-HPLC for the P1, P2 and P3 proteins are shown in Fig. 2. Table 4 shows their $\mathrm{N}$-terminal amino acid sequences, molecular masses measured by ESI-MS and predicted isoelectric points.

Compound P1 presented the $N$-terminal sequence KYYGNGVHXGKHSXTV, containing the consensus region YGNGV, considered a signature of class IIa bacteriocins [15], and also described in bacteriocin Sakacin P [26]. This result confirms the previous report of Rosa et al. [39] for the bacteriocin produced by L. sakei 2a. Sakacin $\mathrm{P}$ produces pores on bacterial cell membranes probably by insertion of its $\mathrm{N}$-terminal region into the bilayer and interaction of the C-terminal domain with specific receptors, causing leakage of some cellular components, but without lysis since the pore formation is transient. Investigations using tryptophan fluorescence spectroscopy on the interaction of Sakacin P analogues with liposomes suggest that this bacteriocin is very selective for bilayers containing anionic phospholipids that are typical of bacterial membranes [17].

The sequence GKTVVRSNESLDDALRRFKRSVSK AGTIQEYRKR, obtained by Edman degradation for compound $\mathrm{P} 2$, is identical to the $30 \mathrm{~S}$ ribosomal protein $\mathrm{S} 21$ of L. monocytogenes 1/2a F6854, E. faecalis v583 and of L. sakei subsp. sakei $23 \mathrm{~K}$ [10]. This similarity suggests that this protein may be active against $L$. monocytogenes and E. faecalis, probably by interfering with ribosome assembly and function, thus hampering protein synthesis and thus leading to the cell death. Other ribosomal proteins were also identified by Edman degradation and mass spectrometry (omitted data), but their antimicrobial activity could be assayed due to the low amount. Nevertheless, this result indicates that $L$. sakei 2 a secretes many ribosomal proteins.

The N-terminal sequence determined for compound P3 was NKAQLIENVASKTGLTKKDATAAVDAVFGSIQ DTLKQGDKVQLIXFGTF, identical to a DNA-binding HV histone produced by L. sakei subsp. sakei $23 \mathrm{~K}$ [10]. Like P2, this component may also interfere in the DNA structure and replication of L. monocytogenes and E. faecalis targets, causing cell death.

The successful cloning and expression of the genes for sakacin $(\mathrm{P} 1), 30 \mathrm{~S}$ ribosomal protein $(\mathrm{P} 2)$ and histone $(\mathrm{P} 3)$ in transformed E. coli KRX confirmed that each one of these compounds presented antilisterial activity in addition

Table 2 Partial purification of antimicrobial compounds produced by L. sakei subsp. sakei 2a in MRS broth

\begin{tabular}{llllllll}
\hline Sample & $\begin{array}{l}\text { Volume } \\
(\mathrm{ml})\end{array}$ & $\begin{array}{l}\text { Activity } \\
(\mathrm{UA} / \mathrm{ml})\end{array}$ & $\begin{array}{l}\text { Total } \\
\text { activity } \\
(\mathrm{UA})\end{array}$ & $\begin{array}{l}\text { Protein } \\
(\mathrm{mg} / \mathrm{ml})\end{array}$ & $\begin{array}{l}\text { Total } \\
\text { protein } \\
(\mathrm{mg})\end{array}$ & $\begin{array}{l}\text { Specific } \\
\text { activity } \\
(\mathrm{UA} / \mathrm{mg})\end{array}$ & $\begin{array}{l}\text { Purification } \\
\text { factor }\end{array}$ \\
\hline Supernatant (broth) & 3,000 & 200 & $6.0 \times 10^{5}$ & 0.29 & 870 & 690 & 1 \\
Crude extract obtained by $\mathrm{H}_{3} \mathrm{PO}_{4}$ treatment $(\mathrm{pH} 1.5)$ & 200 & 100 & $2.0 \times 10^{4}$ & 0.050 & 10 & 2,000 & 2.90 \\
Mono-S cation-exchange chromatography & 24 & 800 & $1.9 \times 10^{4}$ & 0.021 & 0.504 & 38,000 & 55.2 \\
\hline
\end{tabular}


Table 3 Antibacterial spectrum of P1, P2 and P3 proteins produced by $L$. sakei subsp. sakei $2 \mathrm{a}$, assayed by the spot on the lawn test

\begin{tabular}{|c|c|c|c|}
\hline Target strains & P1 & $\mathrm{P} 2$ & P3 \\
\hline Bacillus cereus ATCC 11778 & - & - & - \\
\hline Bifidobacterium bifidum (BB 12) & - & - & - \\
\hline Enterobacter aerogenes ATCC 13048 & - & - & - \\
\hline Enterococcus canis 33 & + & - & - \\
\hline Enterococcus faecalis ATCC 19483 & + & + & + \\
\hline Enterococcus faecium 988 & + & - & - \\
\hline Enterococcus hirae 28 & + & - & - \\
\hline Escherichia coli ATCC 8739 & - & - & - \\
\hline Escherichia coli $\mathrm{O} 157: \mathrm{H} 7$ ATCC 35150 & - & - & - \\
\hline Lactobacillus acidophilus (LA 5) & - & - & - \\
\hline Lactobacillus acidophilus (LAC 4) & - & - & - \\
\hline Lactobacillus casei (BL 20) & - & - & - \\
\hline Lactobacillus helveticus 1176 & - & - & - \\
\hline Lactobacillus sakei ATCC 15521 & + & + & + \\
\hline Lactobacillus paracasei (LBC 82) & - & - & - \\
\hline Lactococcus lactis subsp. lactis 9 & - & - & - \\
\hline Listeria innосиа Li7 & + & + & + \\
\hline Listeria monocytogenes ATCC 7644 & - & - & - \\
\hline Listeria monocytogenes Scott A & + & + & + \\
\hline Listeria seeligeri & + & + & + \\
\hline Salmonella enteriditis ATCC 13076 & - & - & - \\
\hline Salmonella typhimurium ATCC 14028 & - & - & - \\
\hline Staphylococcus aureus subsp. aureus ATCC 6541 & - & - & - \\
\hline Staphylococcus aureus subsp. aureus ATCC 29213 & - & - & - \\
\hline Staphylococcus epidermidis & + & + & + \\
\hline Shigella sonnei & - & - & - \\
\hline Pseudomonas aeruginosa 25723 & - & - & - \\
\hline Pseudomonas mirabilis & - & - & - \\
\hline
\end{tabular}

+ , antimicrobial activity; - , absence of antimicrobial activity

to their own primary function in the cases of the ribosomal protein and the histone.

All these anti-Listeria peptides present isoelectric points higher than 9.0 and typically around 10.0. A high affinity for the anionic surfaces of the bacteria cell wall and phosphate group of nucleic acids is thus expected. The secretion pathway is not well understood, but it is well known that polycationic peptides, especially those rich in arginine residues, can cross lipid bilayers without causing leakage of cell components $[19,38,45,46]$. Other researchers suggest that cationic peptides and proteins cross the cell membranes through an endocytosis process $[18,28]$. A prototype for a cell-penetrating antimicrobial peptide is Buforin II, a histone fragment isolated from the gastric tissue of the Asian toad (Bufo bufo garagrizans). Buforin II is capable of crossing lipid bilayers with minimal perturbation, but causes cell death by intracellular effects because of its strong affinity for nucleic acids [37].
Concerning the ribosomal proteins, it can be hypothesized that if a given bacteria secretes part of their synthesized ribosomal proteins, it can interfere with ribosomal assembly of closely related bacteria. Wool [48] cited various non-lethal functions for ribosomal proteins, and the present study suggests that ribosomal peptides secreted by $L$. sakei $2 \mathrm{a}$ can be viewed as new examples of cell-penetrating antimicrobial proteins [48].

Preliminary characterization of the antagonistic activity confirmed the proteinaceous nature of the antimicrobial compounds secreted by L. sakei 2a. These compounds were sensitive to proteolytic enzymes, heat stable (maintaining the biological activity after heating at 60, 98 and $121^{\circ} \mathrm{C}$ for $\left.15 \mathrm{~min}\right)$ and active in a broad range of $\mathrm{pH}(1.5$ up to 10.0) (Lima et al. submitted). Their antibacterial spectra of the peptides and proteins are similar (Table 3), and probiotic cultures and gram-negative strains were resistant to all these compounds. Despite presenting antilisterial activity, preliminary results indicate that the mechanism of action of these three peptides is not the same. Tests with the fluorescence probes DiSC3(5) and BCECF indicated that the three compounds caused dissipation of membrane potential $(\Delta \Psi)$ in $L$. monocytogenes Scott A (Fig. 3), but only P1 caused dissipation of $\Delta \mathrm{pH}$ (Fig. 4). The P2 and P3 proteins do not disrupt the $\mathrm{pH}$ gradient, but have a significant impact on the membrane potential of this sensitive strain. This is consistent with the idea that the ribosomal protein and the histone do not cause extensive membrane disruption to affect the ATP synthase function. Other experiments indicated that the three antimicrobial compounds caused more dissipation of $\Delta \Psi$ and $\Delta \mathrm{pH}$ than nisin $\left(1 \mathrm{mmol} \mathrm{l}^{-1}\right)$ and enterocin CRL35 $\left(1 \mu \mathrm{mol} \mathrm{l}^{-1}\right)$. Modification of $\Delta \Psi$ has been described already with other class IIa bacteriocins like enterocin P [24, 25] or piscicocin CS526 [43].

Recently, Vera Pingitore et al. [47] analyzed the generation of a $\Delta \mathrm{pH}$ in E. faecalis MP97 cells by determining changes in intracellular $\mathrm{pH}$ with the $\mathrm{pH}$-sensitive fluorescent probe cFDASE. Modifications in the fluorescence intensity of this reagent by extrusion or loss of intracellular cFDASE indicated depletion of membrane $\Delta \mathrm{pH}$. The fluorescence intensity of the probe was increased upon addition of $\mathrm{Sal} \alpha$ and $\mathrm{Sal} \beta$ (different bacteriocins), indicating depletion of membrane $\Delta \mathrm{pH}$ of the sensitive strain. The capacity of $\operatorname{Sal} \alpha$ and $\operatorname{Sal} \beta$ to dissipate $\Delta \psi$ in the E. faecalis MP97-sensitive strain was determined using the fluorescence intensity of the cyanine dye DiSC3(5). In cells energized with glucose, rapid quenching of fluorescence was detected upon addition of the dye, showing the generation of $\Delta \psi$. After the addition of $\operatorname{Sal} \alpha$ and $\operatorname{Sal} \beta$, an increase in the fluorescence intensity of DiSC3(5) was observed, indicating that the $\Delta \psi$ of E. faecalis MP97 was dissipated. $\operatorname{Sal} \alpha$ and $\operatorname{Sal} \beta$ dissipated the $\Delta \psi$ of the sensitive 


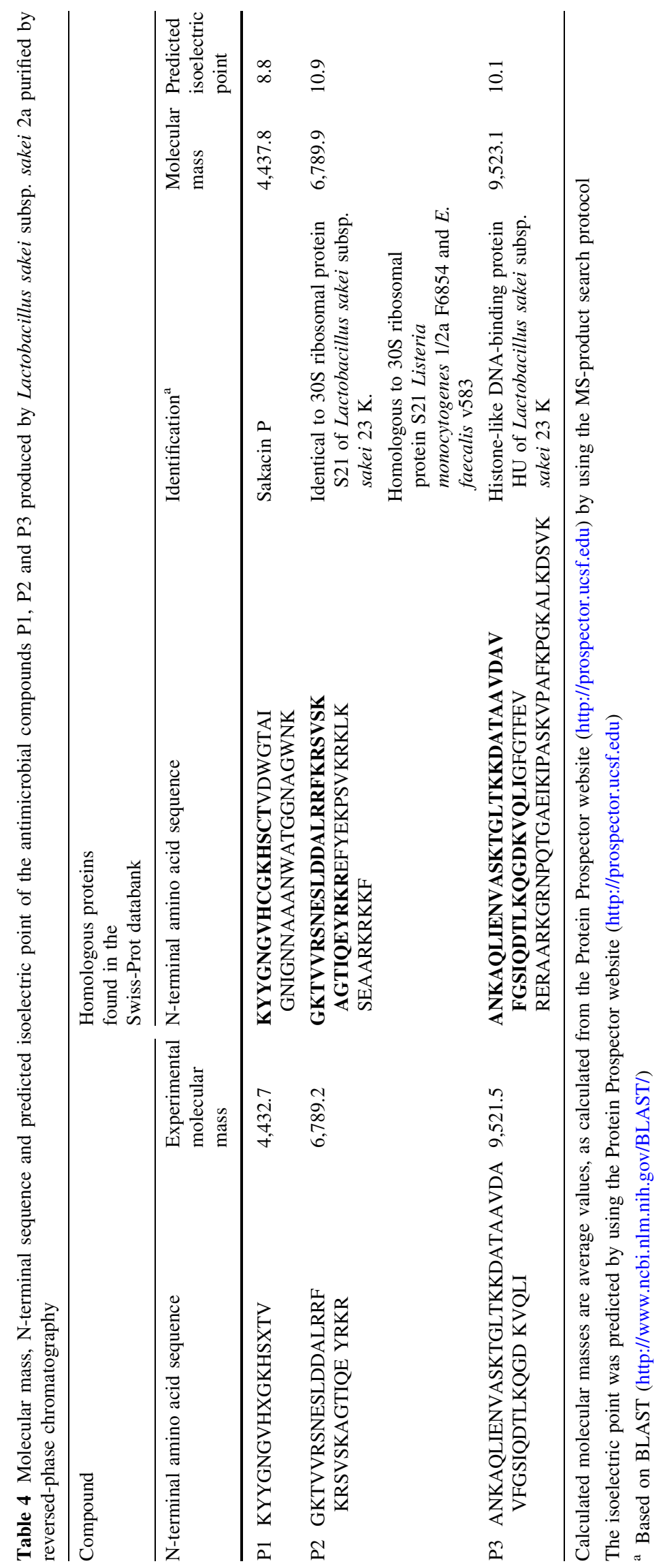



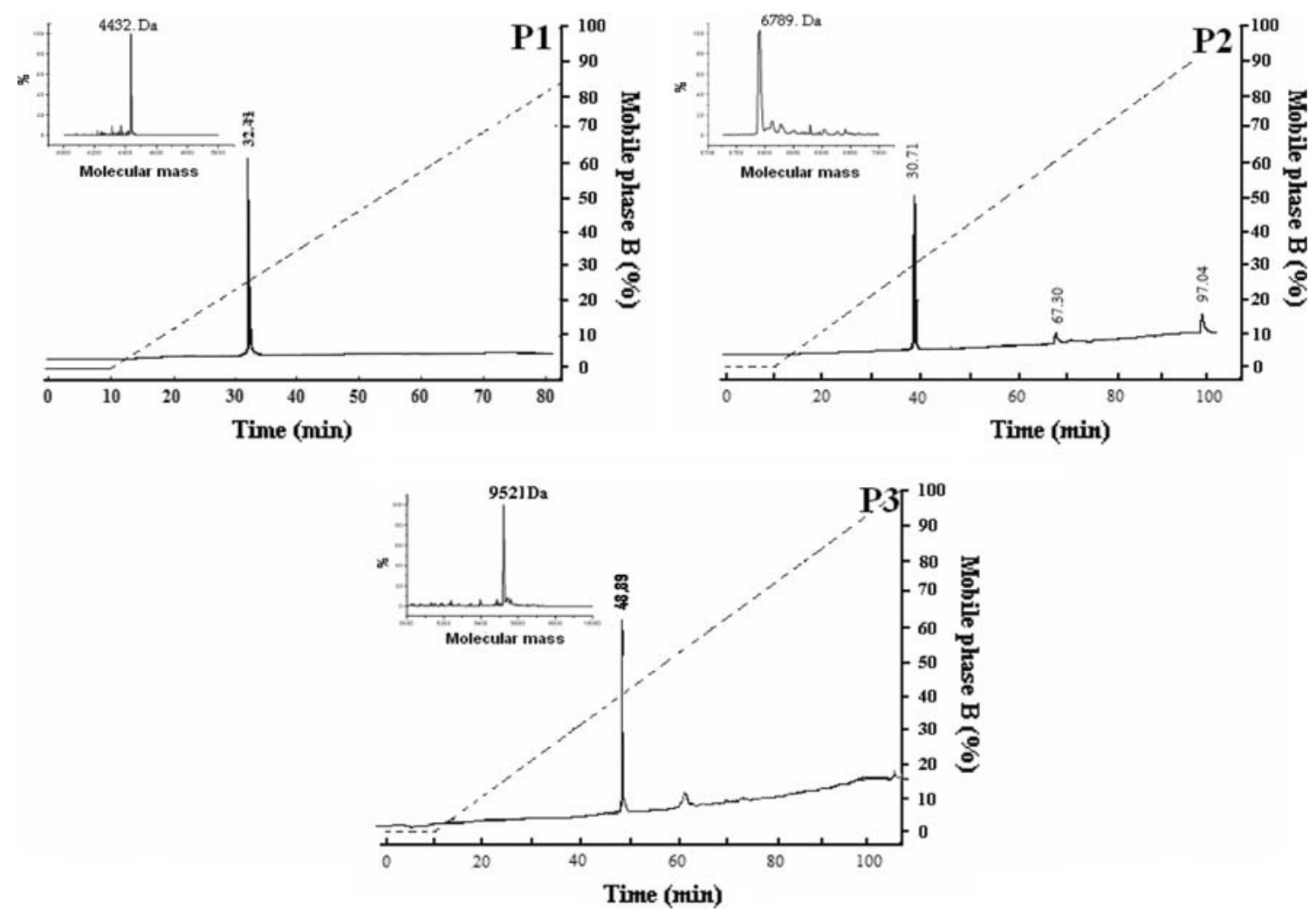

Fig. 2 Reversed-phase chromatographic profile of the purified bacteriocin $(\mathrm{P} 1)$, ribosomal protein $(\mathrm{P} 2)$ and histone $(\mathrm{P} 3)$. Separation was conducted in a Shim-Pack ODS column $(250 \times 4.6 \mathrm{~mm}, 5 \mu \mathrm{m})$ at room temperature. Mobile phases $\mathrm{A}$ and $\mathrm{B}$ were $0.1 \%$ aqueous trifluoroacetic acid (TFA) and $80 \%$ aqueous acetonitrile containing

strain more gradually than that obtained with the $\mathrm{K}^{+}$ionophore valinomycin at $1 \mu \mathrm{M}$.

This is the first report showing that the activity of the classical sakacin $\mathrm{P}$ produced by $L$. sakei $2 \mathrm{a}$ can be

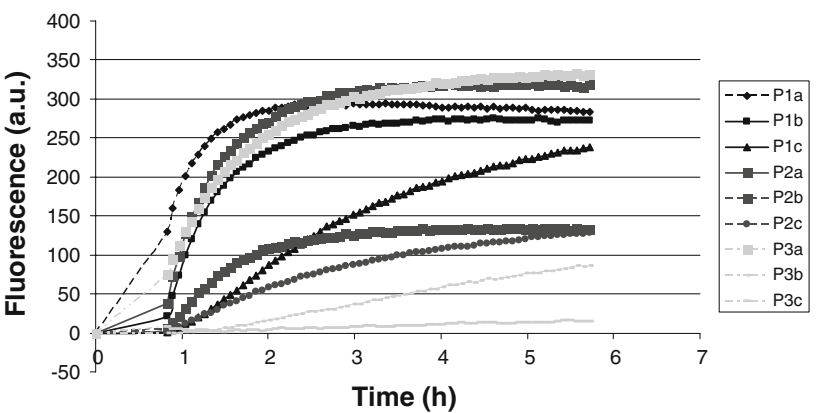

Fig. 3 Effect of the purified P1, P2 and P3 antimicrobial compounds produced by $L$. sakei 2 a on the $\Delta \Psi$ of $L$. monocytogenes Scott A cells. Fluorescence levels before the addition of purified P1, P2 and P3 antimicrobial compounds were arbitrarily designated zero, and the increase in fluorescence upon the addition of bacteriocins

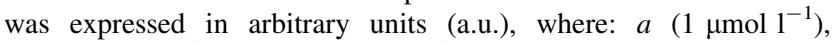
$b\left(100 \mathrm{nmol}^{-1}\right)$ and $c\left(10 \mathrm{nmol}^{-1}\right)$
$0.1 \%$ TFA, respectively; the flow rate was $1.0 \mathrm{ml} \mathrm{min}^{-1}$, and detection was conducted at $280 \mathrm{~nm}$. The dashed line indicates the variation of percentage of mobile phase $B$. The inserts show the deconvoluted ESI Q-TOF (Micromass, Manchester, UK) mass spectra and the calculated molecular masses

complemented by other antimicrobial proteins with unexpected and distinct antibacterial mechanisms. This diversity of antagonistic compounds probably results in different

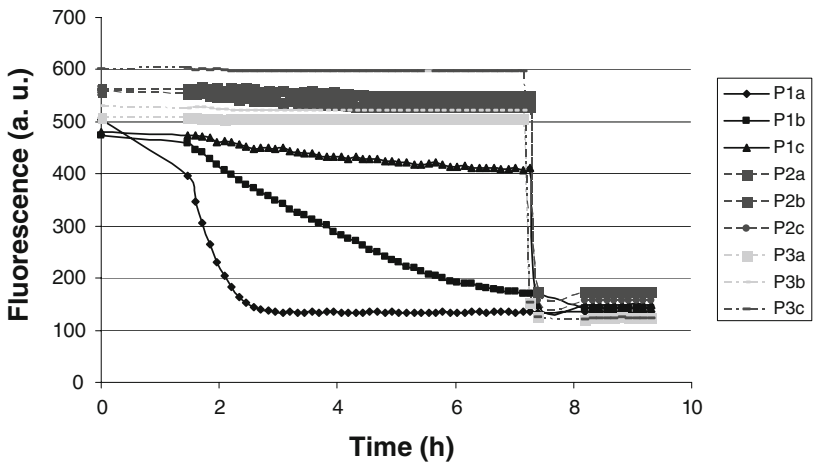

Fig. 4 Effect of the purified P1, P2 and P3 antimicrobial compounds produced by $L$. sakei $2 \mathrm{a}$ on the $\Delta \mathrm{pH}$ of $L$. monocytogenes Scott A cells. Fluorescence levels before the addition of purified P1, P2 and P3 antimicrobial compounds were arbitrarily designated zero, and the increase in fluorescence upon the addition of bacteriocins was expressed in arbitrary units (a.u.). After $7 \mathrm{~min}$, nigericin $\left(1.5 \mathrm{nmol} \mathrm{l}^{-1}\right)$ was added, where: $a\left(1 \mu \mathrm{mol} \mathrm{l}^{-1}\right), b\left(100 \mathrm{nmol} \mathrm{l}^{-1}\right)$ and $c\left(10 \mathrm{nmol}^{-1}\right)$ 
mechanisms acting simultaneously, which makes the development of bacterial resistance more difficult.

Acknowledgments The study was supported by FAPESP (Processes 2004/08041-9 and 2005/60619-8) and FAPEMIG (EDT $24.000)$ grants. F.H.S.B. and M.F.K. are recipients of $\mathrm{CNPq}$ and CAPES scholarships, respectively. K.G.C. and M.S.B. are recipients of FAPESP scholarships.

\section{References}

1. Anastasiadou S, Papagianni M, Filiousis G, Ambrosiadis I, Koidis P (2008) Pediocin SA-1, an antimicrobial peptide from Pediococcus acidilactici NRRL B5627: production conditions, purification and characterization. Bioresour Technol 99:53845390

2. Asaduzzaman SM, Sonomoto K (2009) Lantibiotics: diverse activities and unique modes of action. J Biosci Bioeng 107:475487

3. Atrih A, Rekhif N, Moir AJG, Lebrihi A, Lefebvre G (2001) Mode of action, purification and amino acid sequence of plantaricin C19, an anti-Listeria bacteriocin produced by Lactobacillus plantarum $\mathrm{C} 19$. Int J Food Microbiol 68:93-109

4. Bambirra FHS, Lima KGC, Franco BDGM, Carmona DCM, Nardi RMD, Barbosa FHF, Nicoli JR (2007) Protective effect of Lactobacillus sakei 2a against experimental challenge with Listeria monocytogenes in gnotobiotic mice. Lett Appl Microbiol 45:663-667

5. Bauer R, Chikindas ML, Dicks LMT (2005) Purification, partial amino acid sequence and mode of action of pediocin PD-1, a bacteriocin produced by Pediococcus damnosus NCFB 1832. Int J Food Microbiol 101:17-27

6. Ben-Shushan G, Zakin V, Gollop N (2003) Two different propionicins produced by Propionibacterium thoenii P-127. Peptides 24:1733-1740

7. Bradford MM (1976) Rapid and sensitive method for quantification of microgram quantities of proteins utilizing principle of protein-dye binding. Anal Biochem 72:248-254

8. Brogden KA (2005) Antimicrobial peptides: pore formers or metabolic inhibitors in bacteria. Nat Rev Microbiol 3:238-250

9. Carolissen-Mackay V, Arendse G, Hastings JW (1997) Purification of bacteriocins of lactic acid bacteria: problems and pointers. Int J Food Microbiol 34:1-16

10. Chaillou S, Champomier-Verges M, Cornet M, Crutz Lecoq A-M, Dudez A-M, Martin V, Beaufils S, Darbon-Rongere E, Bossy R, Loux V, Zagorec M (2005) The genome sequence of the meat-borne lactic acid bacterium Lactobacillus sakei $23 \mathrm{~K}$. Nat Biotechnol 23:1527-1533

11. Chumchalová J, Stiles J, Josephsen J, Plocková M (2004) Characterization and purification of acidocin $\mathrm{CH} 5$, a bacteriocin produced by Lactobacillus acidophilus CH5. J Appl Microbiol 96:1082-1089

12. Cotter PD, Hill C, Ross RP (2005) Bacteriocins: developing innate immunity for foods. Nat Rev 3:777-788

13. De Martinis ECP, Franco BDGM (1998) Inhibition of Listeria monocytogenes in a pork product by a Lactobacillus sake strain. Int J Food Microbiol 42:119-126

14. Deegan LH, Cotter PD, Hill C, Ross P (2006) Bacteriocins: biological tools for bio-preservation and shelf-life extension. Int Dairy J 16:1058-1071

15. Drider D, Fimland G, Héchard Y, McMullen LM, Prévost H (2006) The continuing story of class IIa bacteriocins. Microbiol Mol Biol Rev 70:564-582
16. Farias LM, Totola AH, Miranda CMS, Carvalho MAR, Damasceno CAV, Tavares CAP, Cisalpino EO, Vieira EC (1994) Extraction, partial purification and characterization of a bacteriocin (fragilicin) produced by a strain of Bacteroides fragilis isolated from Callithrix penicillata. Res Microbiol 145:9-16

17. Fimland G, Pirneskoski J, Kaewsrichan J, Jutila A, Kristiansen PE, Kinnunen PKJ, Nissen-Meyer J (2006) Mutational analysis and membrane-interactions of the $\mathrm{b}$-sheet-like $\mathrm{N}$-terminal domain of the pediocin-like antimicrobial peptide sakacin P. Biochim Biophys Acta 1764:1132-1140

18. Fischer PM (2007) Cellular uptake mechanisms and potential therapeutic utility of peptidic cell delivery vectors: progress 2001-2006. Med Res Rev 27:755-795

19. Futaki S (2005) Membrane-permeable arginine-rich peptides and the translocation mechanisms. Adv Drug Deliv Rev 57:547-558

20. Gálvez A, Abriouel H, López RL, Ben Omar N (2007) Bacteriocin-based strategies for food biopreservation. Int $\mathrm{J}$ Food Microbiol 30:51-70

21. Ghrairi T, Frere J, Berjeaud JM, Manai M (2008) Purification and characterisation of bacteriocins produced by Enterococcus faecium from Tunisian rigouta cheese. Food Control 19:162-169

22. Hartnett J, Jill MS, Gracyalny BS, Slater MR (2006) The single step (KRX) competent cells: efficient cloning and high protein yields. Promega Notes 94:27-30

23. Heng NC, Burtenshaw GA, Jack RW, Tagg JR (2007) Ubericin A, a class IIa bacteriocin produced by Streptococcus uberis. Appl Environ Microbiol 73:7763-7766

24. Herranz C, Cintas LM, Hernandez PE, Moll GN, Driessen AJ (2001) Enterocin P causes potassium ion efflux from Enterococcus faecium T136 cells. Antimicrob Agents Chemother 45:901-904

25. Herranz C, Chen Y, Chung HJ, Cintas LM, Hernandez PE, Montville TJ, Chikindas ML (2001) Enterocin P selectively dissipates the membrane potential of Enterococcus faecium T136. Appl Environ Microbiol 67:1689-1692

26. Holck AL, Axelsson L, Huhnek K, Krockel L (1994) Purification and cloning of sakacin-674, a bacteriocin from Lactobacillus sake LB674. FEMS Microbiol Lett 115:143-149

27. Jamuna M, Jeevaratnam K (2004) Isolation and partial characterization of bacteriocins from Pediococcus species. Appl Microbiol Biotechnol 65:433-439

28. Jasniewski J, Cailliez-Grimal C, Millière J-B, Revol-Junelles A-M (2008) Functional differences in Leuconostoc sensitive and resistant strains to mesenterocin 52A, a class IIa bacteriocin. Appl Microbiol Biotechnol 81:339-347

29. Kamoun F, Mejdoub H, Aouissaoui H, Reinbolt J, Hammami A, Jaoua S (2005) Purification, amino acid sequence and characterization of Bacthuricin F4, a new bacteriocin produced by Bacillus thuringensis. J Appl Microbiol 98:881-888

30. Kemperman R, Jonker M, Nauta A, Kuipers OP, Kok J (2003) Functional analysis of the gene cluster involved in production of the bacteriocin circularin A by Clostridium beijerinckii ATCC 25752. Appl Environ Microbiol 69:5839-5848

31. Klaenhammer TR (1993) Genetics of bacteriocins produced by lactic acid bacteria. FEMS Microbiol Rev 12:39-85

32. Knoetze H, Todorov SD, Dicks LM (2008) A class IIa peptide from Enterococcus mundtii inhibits bacteria associated with otitis media. Int J Antimicrob Agents 31:228-234

33. Liserre AM, Landgraf M, Destro MT, Franco BDGM (2002) Application of a bacteriocinogenic Lactobacillus sake strain to prevent growth of Listeria monocytogenes in Brazilian sausages ("lingüiça") packaged under modified atmosphere. Meat Sci 61:449-455

34. Lopez RS, Garcia MT, Abriouel H, Omar NB, Grande MJ, Martinez-Canamero M, Gálvez A (2007) Semi-preparative scale purification of enterococcal bacteriocin enterocin EJ97, and 
evaluation of substrates for its production. J Ind Microbiol Biotechnol 34:779-785

35. Moll GN, Konings WN, Driessen AJ (1999) Bacteriocins: mechanism of membrane insertion and pore formation. Antonie Van Leeuwenhoek 76:185-198

36. Nissen-Meyer J, Rogne P, Oppegård C, Haugen HS, Kristiansen PE (2009) Structure-function relationships of the non-lanthionine-containing peptide (class II) bacteriocins produced by grampositive bacteria. Curr Pharm Biotechnol 10:19-37

37. Park CB, Yi KS, Matsuzaki K, Kim MS, Kim SC (2000) Structureactivity analysis of buforin II, a histone H2A-derived antimicrobial peptide: the proline hinge is responsible for the cell-penetrating ability of buforin II. Proc Nat Acad Sci USA 97:3245-3250

38. Prochiantz A (2000) Messenger proteins: homeoproteins, TAT and others. Curr Opin Cell Biol 12:400-406

39. Rosa CM, Franco BDGM, Montville TJ, Chikindas M (2002) Purification and mechanistic action of a bacteriocin produced by a Brazilian sausage isolate, Lactobacillus sake 2a. J Food Saf 22:39-54

40. Saavedra L, Castellano P, Sesma F (2004) Purification of bacteriocins produced by lactic acid bacteria. Methods Mol Biol 268:331-336

41. Schneider R, Fernadez FJ, Aguilar MB, Guerreo-Legaretta I, Alpuche-Solis A, Ponce-Alquicira E (2006) Partial characterization of a class IIa pediocin produced by Pediococcus parvulus 133 strain isolated from meat (Mexican "chorizo"). Food Control 17:909-915
42. Shai Y (1999) Mechanism of the binding, insertion and destabilization of phospholipid bilayer membranes by alpha-helical antimicrobial and cell non-selective membrane-lytic peptides. Biochim Biophys Acta 1462:55-70

43. Suzuki M, Yamamoto T, Kawai Y, Inoue N, Yamazaki K (2005) Mode of action of piscicocin CS526 produced by Carnobacterium piscicola CS526. J Appl Microbiol 98:1146-1151

44. Todorov SD, Dicks LMT (2005) Characterization of bacteriocins produced by lactic acid bacteria isolated from spoiled black olives. J Basic Bacteriol 36:318-326

45. Thorén PEG, Persson D, Karlsson M, Nordén B (2000) The antennapedia peptide penetratin translocates across lipid bilayers the first direct observation. FEBS Lett 482:265-268

46. Thorén PEG, Persson D, Lincoln P, Nordén B (2005) Membrane destabilizing properties of cell-penetrating peptides. Biophys Chem 114:169-179

47. Vera Pingitore E, Hébert EM, Sesma F, Nader-Macias ME (2009) Influence of vitamins and osmolites on growth and bacteriocin production by Lactobacillus salivarius CRL 1328 in a chemically defined medium. Can J Microbiol 55:304-310

48. Wool IG (1996) Extraribosomal functions of ribosomal proteins. Trends Biochem Sci 21:164-165

49. Yang R, Johnson MC, Ray B (1992) Novel method to extract large amounts of bacteriocins from lactic acid bacteria. Appl Environ Microbiol 58:3355-3359 